Egyptian J. of Nutrition Vol. XXXIII No. 2 (2018)

\title{
Effect of Garlic and Mackerel Fish on Rats Suffering From Obesity
}

\section{Omnia G. Refaat - Ashraf A. Abd-elmeged and Omnia W.Darwish}

\author{
Department of Nutrition and Food Science, Faculty of Home \\ Economics, Helwan University, Cairo, Egypt
}

\begin{abstract}
The present work was conducted to study the effect of two levels from mackerel fish, garlic and their combinations on loss of weight, serum glucose, leptin hormone, lipid fraction and kidney functions of obese rats. Forty-eight albino rats (Sprague Dawley Strain) were divided into two main groups. The first main group (6 rats) fed on basal diet was considered control negative group. The second main group (42 rats) fed on high fat diet (HFD) for 6 weeks to induce obesity. Obese rats were randomly assigned to seven equal subgroups: The first subgroup fed on HFD as positive control group, subgroups 2 and 3 fed on high fat containing 2.5\% and $5 \%$ garlic powder, respectively. Subgroup 4 and 5 fed on high fat diet containing mackerel fish, which provided the diets with $50 \%$ and $100 \%$ protein, respectively. Subgroup 6 and 7 fed on high fat diet containing $2.5 \%$ garlic powdered and half amount of protein from mackerel fish and $5 \%$ garlic powdered and all amount of protein from mackerel fish, respectively.Feeding rats on high fat diet led to significant increase in weights, body weight gain \%, serum "glucose, leptin hormone, cholesterol, triglyceride, low density lipoproteincholesterol, very low density lipoprotein-cholesterol, uric acid, urea
\end{abstract}




\section{Omnia G. Refaat - Ashraf A. Abd-elmeged and Omnia W.Darwish}

nitrogen and creatinine, while high density lipoprotein cholesterol decreased, as compared to healthy rats fed on basal diet. Treating obese rats with all tested diet showed significant decrease in weight and body weight gain\%, in addition to improve all parameters. The best results recorded for the group which treated with HFD containing $5 \%$ garlic powdered and $100 \%$ of protein from mackerel fish. Our results indicated 1 that garlic and mackerel fish enhances the health status of obese rats and reduced the weight gain.

\section{Introduction}

Obesity occurs when the body's energy intake exceeds the body's energy consumption for a prolonged period. The degree of obesity is characterized by the volume and number of adipocytes, which is regulated in the so-called adipocyte life cycle (Rayalam et al., 2008). Obesity is associated with many metabolic diseases, including cardiovascular disease, diabetes mellitus, high blood pressure, atherosclerosis, various cancers, and hyperlipidemia (Achike et al., 2011). Thus, treatmentstargeting the regulation of adipocyte size and numbermay provide a therapeutic approach (Rosen et al., 2000).

Allium sativum, or commonly known as garlic, is a vegetable species that can be classified as either a food or a medicinal herb. A widely used plant product is cultivated all over the world. Garlic falls into a family of Amaryllidaceaeor the genus Allium. Its closest relatives in the onion genus include the onion, shallot, leek, rakkyo and chive (Block, 2010). 


\section{Egyptian J. of Nutrition Vol. XXXIII No. 2 (2018)}

Garlic contains at least 33 sulfur compounds, several enzymes and the minerals germanium, calcium, copper, iron, potassium, magnesium, selenium and zinc; vitamins $A, B 1$ and $C$, fiber and water. It also contains 17 amino acids to be found in garlic: lysine, histidine, arginine, aspartic acid threonine, swine, glutamine, proline, glycine, alanine, cysteine, valine, methionine, isoleucine, leucine, tryptophan and phenylalanine (Josling, 2005).

Interestingly it has been observed that chronic administration of raw garlic RG significantly reduced body weight, however the mechanism as to how garlic contributes to a reduction in body weight is still unclear. A study by Elkayam et al., (2003)has showed \l that allicin administered for 2-3 weeks reduced weight gain in fructose fed rats. Together with reducing glucose levels allicin also has the added advantage of decreased weight gain.

Lau et al., (2006)found that aged garlic extract was effective in lowering serum cholesterol and triglycerides. Study by Mahmoodi et al., (2006)conducted on 30 volunteer individuals with blood cholesterol higher than $245 \mathrm{mg} / \mathrm{dl}$. The subjects ingested $5 \mathrm{~g}$ raw garlic twice a day for 42 days and then refrained from garlic for next 42 days. After 42 days of garlic consumption the mean of blood total cholesterol $(p<0.001)$ triglycerides $(p<0.01)$ and fasting blood sugar FBS $(p<0.01)$ were reduced significantly, while HDL-c significantly increased $(p<0.001)$. Following 42 days of no garlic consumption total cholesterol $(p<0.001)$, triglycerides and FBS $(p<0.05)$ were significantly increased and HDL-c $(p<0.01)$ decreased. The authors of this study concluded that consumption alone can decrease serum lipids and may be effective in mild cases, but should probably not be relied on as the main therapeutic agent for hyperlipidemia. 


\section{Omnia G. Refaat - Ashraf A. Abd-elmeged and Omnia W.Darwish}

Nestel, (1990) reported that, fish oil decreases the cholesterol absorption in humans, by reduced the synthesis of cholesterol in the liver and lowered cholesterol secretion within VLDL-c Agren et al., (1996) showed that both fasting and postprandial triglyceride concentrations can be decreased with moderate intakes of long-chain n-3 fatty acids either from a fish diet or fish oil and that also pure DHA has a hypotriglyceridemic effect.

The beneficial health effect of dietary fish intake has been known for decades. The lower incidence of cardiovascular disease among populations consuming fish-rich diets has been attributed to a greater proportion of $\omega-3$ polyunsaturated fatty acids (PUFAs) in fish oil. The mechanisms for the cardioprotective effect of fish intake may include antiarrhythmic effects, antithrombotic effects, antiinflammatory effects, hypotensive effects, improved endothelial function, reduced growth of atherosclerotic plaque, and a hypolipidemic effect (Geleijnse et al., 2002 andConnor, 2000). Although the triacylglycerol lowering effect of $\omega-3$ PUFA is evident in normal and hypertriglyceridemichumans and animals (Harris 1996). Therefore,thepresent studywas aimed to investigate the effects of supplemented high fat diet with garlic and mackerel fish on rats suffering from obesity.

\section{Materials and Methods}

\section{Materials}

- Casein, all vitamins, minerals, cellulose, L -Cystine and choline chloridewere purchased from El-Gomhoria Company, Cairo Egypt.

- Hydrogenated oils, soy oil, starch, sucrose, garlic powder and mackerel fish were purchased from local market, Cairo, Egypt. 


\section{Egyptian J. of Nutrition Vol. XXXIII No. 2 (2018)}

- Normal male albino rats (48) of Sprague Dawley Strain obtained from the Laboratory Animal Colony. Ministry of Health and Population, Helwan, Cairo, Egypt.

- Kits: kits used to determine serum glucose, leptin, cholesterol, triglycerides, HDL-c, uric acid, urea nitrogen, creatinine; Aspartate Amino Transferase (AST), Alanine Amine Transferase (ALT) and Alkaline phosphate (ALP) were obtained from Gama tread Company, Cairo, Egypt.

\section{Methods}

\section{Preparation of mackerel fish:}

Raw mackerel fish was firstly eviscerated to separate the head, fins, tail, viscera and backbone, and then the body cavity of fish was washed with tap water to remove any traces of blood.

\section{Cooking of mackerel fish:}

Mackerel was roasted in electrical oven at $260^{\circ} \mathrm{C}$ for $20-30$ minutes. Then, mackerel fish was minced by passing through a home meat chopper and mixed well, and then the mackerel fish was dried in oven at $50^{\circ} \mathrm{C}$ and grind.

\section{The chemical analysis of mackerel fish and flaxseeds} compositions:

Moisture, ash, total protein, total fat were determined according to A.O.A.C. (1990).

\section{Biological Investigation:}

Male albino rats Sprague Dawley Strain (48 rats) weighing $150 \pm 10 \mathrm{~g}$ were housed in well-aerated cages under hygienic condition and fed on basal diet for one week for adaptation according to Reeves et al., 


\section{Omnia G. Refaat - Ashraf A. Abd-elmeged and Omnia W.Darwish}

(1993).After adaptation period, the rats were divided into two main groups as follows:

The first main group (6 rats) fed on basal diet containing (as a control negative group).The second main group (42 rat) was fed 6 week on high fat diet HFD containing hydrogenated oils $19 \%$, soy oil $1 \%$ to provide essential fatty acids, sucrose $10 \%$, casein $20 \%$, cellulose $5 \%$, vitamin mixture $1 \%$, salt mixture $3.5 \%$, choline chloride $0.25 \%$ and the remainder is corn starch to induce obesity in rats (Min et al., 2004). After these periods, the mean value of body weight gain $\%$ (BWG\%) was estimated in the two main groups (control-ve group fed on basal diet and obese group fed on HFD), also blood samples were collected from all rats to estimate the levels of cholesterol and triglycerides (healthy rats was $65.00 \pm 4.151 \mathrm{mg} / \mathrm{dl}$ cholesterol and $46.125 \pm 3.270 \mathrm{mg} / \mathrm{dl}$ triglycerides), while the second main group recorded $(140.236 \pm 6.678 \mathrm{mg} / \mathrm{dl}$ cholesterol and $75.00 \pm 5.800$ $\mathrm{mg} / \mathrm{dl}$ triglycerides), then the rats in the second main group were divided into seven subgroups ( $n=6$ each) according to the following scheme:

Subgroup 1: six rats fed on high fat diet, as a positive control.

Subgroups 2 and 3: fed on high fat diet containing 2.5\% and 5\% garlic powder, respectively.

Subgroups 4 and 5: fed on high fat diet containing half amount and all amount of protein from mackerel fish, respectively.

Subgroup 6 and 7: fed on high fat diet containing 2.5\% garlic powdered and half amount of protein from mackerel fish and $5 \%$ garlic powdered and all amount of protein from mackerel fish, respectively. 


\section{Egyptian J. of Nutrition Vol. XXXIII No. 2 (2018)}

During the experimental period (4 week), the diets consumed and body weights were recorded every week. At the end of the experiment, the rats were fasted overnight, then the rats were anaesthetized and sacrificed, and blood samples were collected from the aorta. The blood samples were centrifuged and serum was separated to estimate some biochemical parameters, i.e. serum total cholesterol according to Allain et al., (1974),triglycerids Fossati et al., (1982), high density lipoprotein Burstein (1970), low density lipoprotein and very low density lipoprotein Friedwald et al., (1972), glucose Trinder, (1959), uric acid Fossati et al., (1980), urea nitrogen Patton and Crouch, (1977), creatinine Bohmer, (1971)and serum leptin hormone Guillaume et al., (1996).

Liver and kidney were separated from each rat and weighted to calculate the liver and kidney to body weight \%. Results of biological evaluation of each group were statistically analyzed (mean \pm standard deviation and one way ANOVA test) using SAS package and compared with each other using the suitable test (least significant differences at $\mathrm{P}<0.05$ (Steel et al., 1980).

\section{Results and Discussion}

\section{Chemical Composition of Mackerel Fish ( $\mathrm{g} / \mathbf{1 0 0 g}$ )}

The percentage of protein was highly in roasted mackerel fish $20.95 \%$, followed by total lipid 25.87 , while the mackerel fish does not contain any carbohydrate, respectively. Roasted mackerel fish does not contain any fiber and contain $3.90 \%$ and $7.23 \%$ ash and moisture, respectively. In this respect, Yu Wei Feng et al., (2012) reported that, crude protein, total lipids, moisture and total ash 


\section{Omnia G. Refaat - Ashraf A. Abd-elmeged and Omnia W.Darwish}

contents of mackerel fish ranged between $21.46 \%-22.75 \%, 2.24 \%$ $8.23 \%, 69.7 \%-74.9 \%$, and $1.25 \%-1.63 \%$, respectively.

Effect of Garlic and Mackerel Fish on feed intake as well as weights and body weight gain\% of Rats ObesitySuffering.

The mean value of feed intake in the positive control group decreased than that of the negative control group. The two levels of garlic, mackerel fish and their combinations increased the mean value of feed intake, than that of the positive control group (Table 2). High fat diet increased the mean values of final weight and body weight gain \% significantly ( $\mathrm{S} \leq 0.05)$, as compared to the negative control group. All HFD treated groups showed significant decrease $\mathrm{P} \leq 0.05$ in the mean value of final weight and body weight gain $\%$, as compared to the positive control group. Treating obese groups with the low levels from garlic and mackerel fish (as a combination)and also the high levels $2.5 \%$ garlic and $50 \%$ of protein from mackerel fish and $5 \%$ garlic and $100 \%$ of protein from mackerel fishrecorded the highest decrease in the mean value of body weight gain $\%$, as compared to healthy rats, obese rats and other treated groups.

Obesity has become a serious worldwide healthcare problem, which is becoming increasingly prevalent among young adults and children (WHO, 1998 and BMA, 2005). It is therefore of great importance to help young overweight adults to lose weight. Inclusion of fish in a weight-loss-diet has been shown to have positive effects on several health-related variables (Mori et al., 1999), which could be due to omega3 fatty acids or other seafood constituents, such as fish proteins as reported in animal studies (Tremblay et al., 2007). 


\section{Egyptian J. of Nutrition Vol. XXXIII No. 2 (2018)}

Beneficial effects of fish consumption in relation to cardiovascular health have been thoroughly described, and mainly attributed to omega3 fatty acids (Dolocek et al ., 1991). Studies in rodents have demonstrated that marine omega3 fatty-acid-enriched diet decrease adipose growth and increase b-oxidation (Nakatani et al., 2003). Additionally, taurine, an amino acid abundant in fish protein, has been suggested to decrease body weight (Fujihira et al., 1970).

Kim et al., (2011) suggest that garlic may have a potential benefit in preventing obesity. On the other hand,Rosen et al., (2000) reported that, garlic supplement significantly decreased fat accumulating gen. Yoonet al., (2005) reported that garlic, associated with significant reductions in body weight gain and fat mass in HFDtreated Sprague-Dawley (SD) rats.

\section{Effect of Garlic and Mackerel Fish on Serum Glucose of Rats Obesity Suffering.}

The effect of two levels of (garlic, mackerel fish and their combination) on serum glucose and leptin of obese rats presented in Table (3). The mean value of serum glucose was increased significantly $\mathrm{P} \leq 0.05$ in positive group fed onHFD diet (obese rats), as compared to the negative control group (healthy rats).The mean value of serum glucose was decreased in all treated groups which were fed on high fat diet with garlic, mackerel fish and their combination, as compared to the positive control group.The highest decrease in serum glucosewas recorded for the HFD groups, treated with the diets containing low and high levels from the combination of garlic and mackerel fish $2.5 \%$ garlic and $50 \%$ of protein from mackerel fish and $5 \%$ garlic and $100 \%$ of protein from mackerel fish.Chiang et al., (1995) and Miura et al.,(1998) reported that, fish oil or dietary 


\section{Omnia G. Refaat - Ashraf A. Abd-elmeged and Omnia W.Darwish}

fish decreased glucose concentration and improved glucose tolerance by increasing insulin secretion capacity from pancreatic beta cells.

Most of the studies showed that garlic could reduce blood glucose level in diabetic mice and rabbits (Ohaeri, 2001). A study was conducted to evaluate oral administration of garlic extract for 14 days on the level of serum glucose. The result of that study showed significant decrease $(p<0.05)$ in serum glucose, while increased serum insulin in diabetic mice, but not in normal mice. (Eidi et al. 2006).

\section{Effect of Garlic and Mackerel Fish on Serum Cholesterol and Triglyceride of Rats ObesitySuffering.}

The mean value of serum leptin was increased by about $142.45 \%$ in obese rats (positive control group), than that of healthy rats (negative control group). All HFD treated groups decreased the mean value of serum leptin significantly $p \leq 0.05$, as compared to the positive control group. On the other hand, serum leptin was decreased gradually with increasing the level of garlic, mackerel fish and their combination, than the positive group.The highest decrease in serum leptin was recorded for the groups, which were treated by the combination of garlic (5\%) and mackerel fish which provided the diet with (100\% protein), because this treatment decreased the mean value of serum leptin, as compared to other treated groups. This treatment decreased the mean value of serum leptin by about $39.18 \%$, than that of the positive control group.

In this respect, leptin promotes weight loss by two different mechanisms. It reduces appetite, and thus food intake, and at the 


\section{Egyptian J. of Nutrition Vol. XXXIII No. 2 (2018)}

same time increases energy expenditure (Murakami et al., 2007 and Kuroda et al., 2010).Higher leptin concentrations have been prospectively implicated as an independent risk factor for stroke, coronary artery disease, and myocardial infarction (Soderberg et al., 1999). Prospective studies have shown that a diet rich in fish or fish oil is related to a low incidence of cardiovascular disease (Daviglus et al., 1997).The mechanisms of the protective effect of fish oil on cardiovascular risk have been attributed mainly to the high concentration of omega3 polyunsaturated fatty acids and their antithrombotic action and modification of immunological processes (Leaf, 1990).

Yoonet al., (2005) reported that garlic, associated with significant reductions in body weight gain and fat mass in HFDtreated rats. Also =Kim et al., (2013) suggested that Allium sativum L. (garlic) stem extract (ASSE) may ameliorate obesity, insulin resistance and oxidative damage in high-fat diet-induced obese mice.

The effect of two levels of garlic (2.5\% and $5 \%)$, mackerel fish (fish provided the diets with $50 \%$ and $100 \%$ protein) and their combination $2.5 \%$ garlic and fish provided the diets with $50 \%$ protein and $5 \%$ garlic and fish provided the diets with $100 \%$ protein) on serum cholesterol, triglycerides, high density lipoprotein-cholesterol (HDL-C), low density lipoprotein-cholesterol (LDL-C) and very low density lipoprotein-cholesterol (VLDL-c )of obese rats presented in Table (4 and 5).

\section{Effect of Garlic and Mackerel Fish on Serum Lipoproteins of} Rats ObesitySuffering.

The mean value of total serum cholesterol and triglycerides was increased significantly $\mathrm{P} \leq 0.05$ in the positive control group, as 


\section{Omnia G. Refaat - Ashraf A. Abd-elmeged and Omnia W.Darwish}

compared to the negative control group. All HFD treated groups showed significant decrease $\mathrm{P} \leq 0.05$ in serum cholesterol, as compared to the positive control group. The highest decrease in serum cholesterol between all HFD tested groupswas recorded for the group, which treated with the combination of $5 \%$ garlic and mackerel fish, which provided the diet with $100 \%$ protein, this treatment decreased the mean value of serum cholesterol by about $35.22 \%$, than that of the positive control group (Table 4).

All HFD treated groups with two levels of garlic, mackerel fish and their combination showed significant decrease $P \leq 0.05$ in serum triglyceride, except that group, which were treated with $2.5 \%$ garlic, and the group treated with mackerel fish, which provided the diet with $50 \%$ of protein. The highest levels of garlic and mackerel fish together (as a combination) recorded the best results in serum triglyceride.

The mean value of serum LDL-C and VLDL-c were decreased significantly $\mathrm{P} \leq 0.05$, while HDL-C was increased in the positive control group (obese rats), as compared to the negative control group (healthy rats) (Table 5).All HFD treated groups with garlic; mackerel fish and their combination showed significant increase in serum HDL$c$ and decreased the mean values of serum LDL-C and VLDL-C, as compared to the positive control group.The best results in the mean value of serum lipoproteins recorded for the HFD group, which treated with high fat diet containing $5 \%$ garlic and mackerel fish which provided the diet with $100 \%$ protein, this treatment increased the mean value of serum HDL-c by about $43.75 \%$, and decreased the mean values of serum LDL-c and VLDL-c by about $56.29 \%$ and $35.73 \%$ respectively, than that of the positive control group. 


\section{Egyptian J. of Nutrition Vol. XXXIII No. 2 (2018)}

Dietary fat is considered one of the important environmental factors contributing to the obesity (Peters, 2003). Fat content is one of the main factors influencing the energy density of diets and an increase in energy density was shown to result in excess intake of calories; passive over consumption in humans in turn promotes the development of obesity (Westerterp-Plantenga, 2004).

Zhang et al., (1993) demonstrated that, different fish proteins in the diet have different effects on cholesterol metabolism. On the other hand, Lowe et al., (1997) stated that, dietary fish oils, which are rich in omega-3 fatty acids, reduced plasma lipid levels in both normollipidemic and hyperlipidemic subjects. Schaefer et al.,(1996) and Shiau et al., (1999) reported that fish oil supplements and diets containingfish are enriched with eicosapentaenoic [20:5(omega3)] and docosahexaenoic [22:6(omega3)] acids and have been found to reduce plasma levelsof triglycerides, especially in the postprandial state. While Viejo et al., (1999) showed that, a 10-day application of a small supplementation of $\omega-3$ fish oil changes the LDL-C composition, leading to less atherogenic index. Connor, (2000) reported that dietary omega3 fatty acids might ameliorate the atherosclerotic process itself, which is the cause of coronary artery disease. Populations that consume more omega3 fatty acids from fish have a lower incidence of coronary artery disease.

Garlic (Allium sativum L.) possesses many healthful properties that are related to its bioactive compounds (Leelarungrayub et al., 2006). Consumption of garlic is very helpful in regulating plasma lipid levels (Lau, 2006)as well as plasma anticoagulant activity (Lawson et al., 1992)and in prevention of the atherosclerosis process (Rahman et al., 2006). 


\section{Omnia G. Refaat - Ashraf A. Abd-elmeged and Omnia W.Darwish}

Health claims advertising garlic's universal ability to lower cholesterol level and decrease lipid peroxidation in order to inhibit plaque formation. In vitro studies clearly have shown that, it has an ability to suppress low density lipoprotein (LDL) and an increased resistance of LDL to oxidation (Lau, 2006).

Jeyaraj et al. (2006) reported that after 60 days of supplementation by garlic fermented with the mold Monascuspilosus,low-density lipoprotein, serum triglyceride and very low density lipoprotein, were reduced by 21,37 , and $36.7 \%$, respectively.

\section{Effect of Garlic and Mackerel Fish on Kidney Function of Rats ObesitySuffering.}

Results in Table (6) illustrate effect of high fat diet containing two levels of garlic, mackerel fish and their combination on serum uric acid, urea nitrogen and creatinine "mg/dl" of obese rats.

The mean values of serum uric acid urea nitrogen and creatinine were increased significantly $\mathrm{P} \leq 0.05$ in rats suffering from obesity, than that of healthy rats.Serum uric acid, urea nitrogen and creatinine were decreased significantly $\mathrm{P} \leq 0.05$ in obese groups, which were treated with the two levels of garlic, mackerel fish and their combinations. The highest decrease in serum uric acid, urea nitrogen and creatinine recorded for the HFDgroups which were treated with high fat diet containing $2.5 \%$ garlic and mackerel fish which provided the diet with $50 \%$ protein and $5 \%$ garlic and mackerel fish which provided the diet with $100 \%$ protein. 


\section{Egyptian J. of Nutrition Vol. XXXIII No. 2 (2018)}

Fassett, et al., (2010) reported that, Omega-3 polyunsaturated fatty acids decrease blood pressure, a known accelerant of kidney disease progression. Well-designed, adequately powered, randomized, controlled clinical trials are required to further investigate the potential benefits of omega-3 polyunsaturated fatty acids on the progression of kidney disease and patient surviva Donadio, (1991) reported that, Omega-3 polyunsaturated fatty acids may limit the production or action of cytokines and eicosanoids evoked by the initial or by repeated immunologic renal injury.Friedman et al., (1996 )reported that omega-3 fatty acids might have clinical benefits; formal recommendations encouraging omega-3 supplementation of dialysis patients are premature until long-term and adverse effects are better defined.

Maldonado et al., (2003) reported that, the protective effect of aged garlic extract (AGE) was associated with the decrease in the oxidative stress and the preservation of manganese superoxide dismutase, glutathione peroxidase, and glutathione reductase activities in renal cortex. These data suggest that AGE may be a useful agent for the prevention of gentamicin GM-nephrotoxicity. 


\section{Omnia G. Refaat - Ashraf A. Abd-elmeged and Omnia W.Darwish}

Table (1): Chemical Composition of Mackerel Fish ( $\mathrm{g} / 100 \mathrm{~g}$ )

\begin{tabular}{c|c}
\hline Nutrient Proximate & $\begin{array}{c}\text { Mackerel } \\
\text { Fish(Roasted) }\end{array}$ \\
\hline Water & 7.23 \\
\hline Protein & 20.95 \\
\hline Total lipid (fat) & 25.87 \\
\hline Carbohydrate, by difference & --- \\
\hline Fiber, total dietary & --- \\
\hline Ash & 3.90 \\
\hline
\end{tabular}




\section{Egyptian J. of Nutrition Vol. XXXIII No. 2 (2018)}

Table (2): Effect of Garlic and Mackerel Fish on feed intake as well as weights and body weight gain\% of Rats ObesitySuffering.

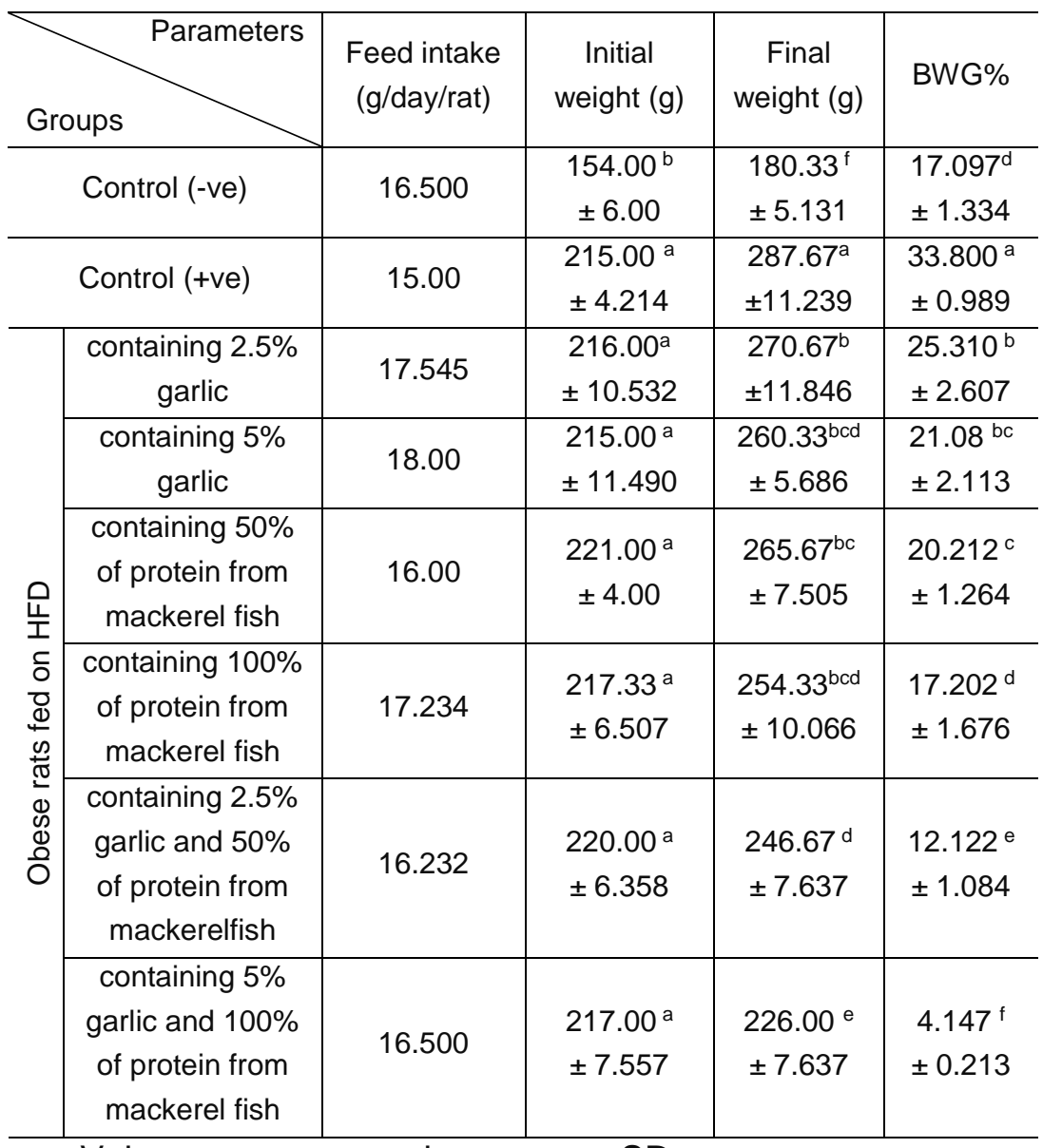

- Values are expressed as mean \pm SD.

- Significant at $p<0.05$ using one way ANOVA test.

- Values which have different letters in each column differ significantly, while those with have similar or partially are not significant. 


\section{Omnia G. Refaat - Ashraf A. Abd-elmeged and Omnia W.Darwish}

Table (3): Effect of Garlic and Mackerel Fish on Serum Glucose of Rats Obesity Suffering.

\begin{tabular}{|c|c|c|c|}
\hline \multicolumn{2}{|c|}{ Groups $\quad$ Parameter } & $\begin{array}{c}\text { Glucose } \\
\mathrm{mg} / \mathrm{dl}\end{array}$ & $\begin{array}{l}\text { Leptin } \\
\mathrm{mg} / \mathrm{dl}\end{array}$ \\
\hline \multicolumn{2}{|r|}{ Control (-) group } & $\begin{array}{l}109.500^{d} \\
\pm 0.577^{d}\end{array}$ & $\begin{array}{r}5.300^{g} \\
\pm 0.424\end{array}$ \\
\hline \multirow{7}{*}{ 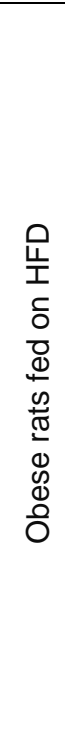 } & only (control +ve) & $\begin{array}{l}143.500^{a} \\
\pm 2.081^{a}\end{array}$ & $\begin{array}{l}12.850^{a} \\
\pm 0.810\end{array}$ \\
\hline & containing $2.5 \%$ garlic & $\begin{array}{l}129.750^{\mathrm{b}} \\
\pm 4.031\end{array}$ & $\begin{array}{l}10.440^{b} \\
\pm 0.425\end{array}$ \\
\hline & containing $5 \%$ garlic & $\begin{array}{c}118.750^{c} \\
\pm 2.629\end{array}$ & $\begin{array}{l}9.562^{\mathrm{cd}} \\
\pm 0.426\end{array}$ \\
\hline & $\begin{array}{l}\text { containing } 50 \% \text { of protein } \\
\text { from mackerel fish }\end{array}$ & $\begin{array}{l}133.500^{b} \\
\pm 3.316\end{array}$ & $\begin{array}{l}9.945^{\mathrm{bc}} \\
\pm 0.461\end{array}$ \\
\hline & $\begin{array}{l}\text { containing } 100 \% \text { of protein } \\
\text { from mackerel fish }\end{array}$ & $\begin{array}{c}119.500^{c} \\
\pm 1.732\end{array}$ & $\begin{array}{l}8.870^{e} \\
\pm 0.215\end{array}$ \\
\hline & $\begin{array}{c}\text { containing } 2.5 \% \text { garlic and } \\
50 \% \text { of protein from } \\
\text { mackerelfish }\end{array}$ & $\begin{array}{l}108.500^{d} \\
\pm 4.041\end{array}$ & $\begin{array}{l}8.967 \mathrm{de} \\
\pm 0.065\end{array}$ \\
\hline & $\begin{array}{c}\text { containing } 5 \% \text { garlic and } \\
100 \% \text { of protein from } \\
\text { mackerel fish }\end{array}$ & $\begin{array}{l}110.00^{d} \\
\pm 8.082\end{array}$ & $\begin{array}{r}7.815^{f} \\
\pm 0.397\end{array}$ \\
\hline
\end{tabular}

All results are expressed as mean \pm SD

Values in each column, which have different litters, are significant different $(P<0.05)$. 
Egyptian J. of Nutrition Vol. XXXIII No. 2 (2018)

Table (4): Effect of Garlic and Mackerel Fish on Serum Cholesterol and Triglyceride of Rats ObesitySuffering.

\begin{tabular}{|c|c|c|c|}
\hline \multicolumn{2}{|c|}{ Groups $\quad$ Parameter } & $\begin{array}{c}\text { Cholesterol } \\
\mathrm{mg} / \mathrm{dl}\end{array}$ & $\begin{array}{c}\text { Triglyceride } \\
\text { mg/dl }\end{array}$ \\
\hline \multicolumn{2}{|r|}{ Control (-) group } & $\begin{array}{l}69.00^{e} \\
\pm 8.082\end{array}$ & $\begin{array}{l}58.250^{d} \\
\pm 7.320\end{array}$ \\
\hline \multirow{7}{*}{ 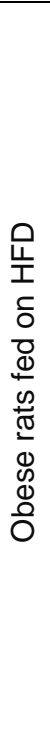 } & only (control +ve) & $\begin{array}{l}150.500^{a} \\
\pm 5.196\end{array}$ & $\begin{array}{l}89.00^{a} \\
\pm 5.830\end{array}$ \\
\hline & containing $2.5 \%$ garlic & $\begin{array}{l}124.00^{b} \\
\pm 2.828\end{array}$ & $\begin{array}{l}80.750 \mathrm{ab} \\
\pm 6.075\end{array}$ \\
\hline & containing $5 \%$ garlic & $\begin{array}{l}112.000^{c} \\
\pm 9.521\end{array}$ & $\begin{array}{l}64.00^{c d} \\
\pm 4.242\end{array}$ \\
\hline & $\begin{array}{l}\text { containing } 50 \% \text { of protein } \\
\text { from mackerel fish }\end{array}$ & $\begin{array}{l}133.500^{b} \\
\pm 6.350\end{array}$ & $\begin{array}{l}79.00^{a b} \\
\pm 8.082\end{array}$ \\
\hline & $\begin{array}{l}\text { containing } 100 \% \text { of protein } \\
\text { from mackerel fish }\end{array}$ & $\begin{array}{l}123.500^{b} \\
\pm 14.433\end{array}$ & $\begin{array}{l}72.500^{b c} \\
\pm 8.660\end{array}$ \\
\hline & $\begin{array}{c}\text { containing } 2.5 \% \text { garlic and } \\
50 \% \text { of protein from } \\
\text { mackerelfish }\end{array}$ & $\begin{array}{l}102.500 \mathrm{~cd} \\
\pm 2.886\end{array}$ & $\begin{array}{l}63.250^{c d} \\
\pm 4.500\end{array}$ \\
\hline & $\begin{array}{c}\text { containing } 5 \% \text { garlic and } \\
100 \% \text { of protein from } \\
\text { mackerel fish }\end{array}$ & $\begin{array}{l}97.500^{d} \\
\pm 6.454\end{array}$ & $\begin{array}{l}58.00^{d} \\
\pm 7.527\end{array}$ \\
\hline
\end{tabular}

All results are expressed as mean \pm SD

Values in each column, which have different litters, are significant different $(P<0.05)$ 


\section{Omnia G. Refaat - Ashraf A. Abd-elmeged and Omnia W.Darwish}

Table (5): Effect of Garlic and Mackerel Fish on Serum Lipoproteins of Rats ObesitySuffering.

\begin{tabular}{|c|c|c|c|c|}
\hline \multicolumn{2}{|c|}{ Groups $\quad$ Parameter } & $\begin{array}{l}\mathrm{HDL}-\mathrm{c} \\
\mathrm{mg} / \mathrm{dl}\end{array}$ & $\begin{array}{l}\mathrm{LDL}-\mathrm{c} \\
\mathrm{mg} / \mathrm{dl}\end{array}$ & $\begin{array}{l}\text { VLDL-c } \\
\mathrm{mg} / \mathrm{dl}\end{array}$ \\
\hline \multicolumn{2}{|r|}{ Control (-) group } & $43.750^{a}$ & $14.100^{f}$ & $11.650^{d}$ \\
\hline \multirow{7}{*}{ 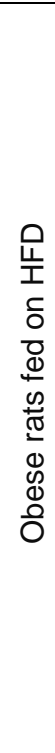 } & only (control +ve) & $\begin{array}{l}28.00^{e} \\
\pm 2.160\end{array}$ & $\begin{array}{l}104.450^{a} \\
\pm 4.196\end{array}$ & $\begin{array}{l}18.050^{a} \\
\pm 1.320\end{array}$ \\
\hline & containing $2.5 \%$ garlic & $\begin{array}{l}34.500^{d} \\
\pm 4.654\end{array}$ & $\begin{array}{l}73.350^{b c} \\
\pm 3.742\end{array}$ & $\begin{array}{l}16.150^{a b} \\
\pm 1.215\end{array}$ \\
\hline & containing $5 \%$ garlic & $\begin{array}{l}38.750^{b c} \\
\pm 0.957\end{array}$ & $\begin{array}{l}60.450^{d} \\
\pm 7.925\end{array}$ & $\begin{array}{l}12.800^{\mathrm{cd}} \\
\pm 0.848\end{array}$ \\
\hline & $\begin{array}{l}\text { containing } 50 \% \text { of protein } \\
\text { from mackerel fish }\end{array}$ & $\begin{array}{l}35.750^{\mathrm{cd}} \\
\pm 2.986\end{array}$ & $\begin{array}{l}81.950^{b} \\
\pm 4.202\end{array}$ & $\begin{array}{r}15.800^{a b} \\
\pm 0.848\end{array}$ \\
\hline & $\begin{array}{l}\text { containing } 100 \% \text { of protein } \\
\text { from mackerel fish }\end{array}$ & $\begin{array}{l}37.500^{\mathrm{bcd}} \\
\pm 0.577\end{array}$ & $\begin{array}{l}71.500^{c} \\
\pm 12.124\end{array}$ & $\begin{array}{l}14.500^{b c} \\
\pm 1.732\end{array}$ \\
\hline & $\begin{array}{c}\text { containing } 2.5 \% \text { garlic and } \\
50 \% \text { of protein from } \\
\text { mackerelfish }\end{array}$ & $\begin{array}{l}35.500^{c d} \\
\pm 1.732\end{array}$ & $\begin{array}{l}51.600 \mathrm{de} \\
\pm 4.819\end{array}$ & $\begin{array}{l}12.650 \mathrm{~cd} \\
\pm 0.900\end{array}$ \\
\hline & $\begin{array}{c}\text { containing } 5 \% \text { garlic and } \\
100 \% \text { of protein from } \\
\text { mackerel fish }\end{array}$ & $\begin{array}{l}40.250 \mathrm{ab} \\
\pm 1.258\end{array}$ & $\begin{array}{l}45.650 \text { e } \\
\pm 6.682\end{array}$ & $\begin{array}{l}11.600^{d} \\
\pm 1.505\end{array}$ \\
\hline
\end{tabular}

All results are expressed as mean \pm SD

Values in each column, which have different litters, are significant different $(P<0.05)$ 


\section{Egyptian J. of Nutrition Vol. XXXIII No. 2 (2018)}

Table (6): Effect of Garlic and Mackerel Fish on Kidney Function of Rats ObesitySuffering.

\begin{tabular}{|c|c|c|c|c|}
\hline \multicolumn{2}{|c|}{$\mathrm{C}_{\text {Parameter }}$} & $\begin{array}{l}\text { Uric acid } \\
\mathrm{mg} / \mathrm{dl}\end{array}$ & $\begin{array}{c}\text { Urea } \\
\text { nitrogen } \\
\text { mg/dl }\end{array}$ & $\begin{array}{l}\text { Creatinine } \\
\mathrm{mg} / \mathrm{dl}\end{array}$ \\
\hline \multicolumn{2}{|r|}{ Control (-) group } & $\begin{array}{r}1.260^{c} \\
\pm 0.048\end{array}$ & $\begin{array}{l}16.900^{e} \\
\pm 0.115\end{array}$ & $\begin{array}{l}0.552^{d} \\
\pm 0.035\end{array}$ \\
\hline \multirow{7}{*}{ 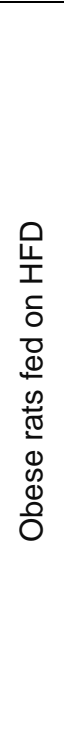 } & only (control +ve) & $\begin{array}{l}2.350^{a} \\
\pm 0.173\end{array}$ & $\begin{array}{l}39.025^{a} \\
\pm 0.543\end{array}$ & $\begin{array}{r}1.587^{a} \\
\pm 0.085\end{array}$ \\
\hline & containing $2.5 \%$ garlic & $\begin{array}{r}1.972^{\mathrm{b}} \\
\pm 0.174 \\
\end{array}$ & $\begin{array}{l}28.075^{b} \\
\pm 1.658 \\
\end{array}$ & $\begin{array}{l}0.757^{c} \\
\pm 0.046 \\
\end{array}$ \\
\hline & containing $5 \%$ garlic & $\begin{array}{l}2.025^{b} \\
\pm 0.086\end{array}$ & $\begin{array}{l}17.00^{\mathrm{e}} \\
\pm 0.905\end{array}$ & $\begin{array}{l}0.760^{c} \\
\pm 0.033\end{array}$ \\
\hline & $\begin{array}{l}\text { containing } 50 \% \text { of protein } \\
\text { from mackerel fish }\end{array}$ & $\begin{array}{l}1.875^{b} \\
\pm 0.095\end{array}$ & $\begin{array}{l}23.250^{c} \\
\pm 0.960\end{array}$ & $\begin{array}{l}0.840^{\mathrm{b}} \\
\pm 0.049\end{array}$ \\
\hline & $\begin{array}{l}\text { containing } 100 \% \text { of protein } \\
\text { from mackerel fish }\end{array}$ & $\begin{array}{l}1.860^{b} \\
\pm 0.110\end{array}$ & $\begin{array}{l}22.800^{c} \\
\pm 0.594\end{array}$ & $\begin{array}{l}0.780^{b c} \\
\pm 0.046\end{array}$ \\
\hline & $\begin{array}{c}\text { containing } 2.5 \% \text { garlic and } \\
50 \% \text { of protein from } \\
\text { mackerelfish }\end{array}$ & $\begin{array}{r}1.440^{c} \\
\pm 0.127\end{array}$ & $\begin{array}{l}19.325^{d} \\
\pm 0.713\end{array}$ & $\begin{array}{l}0.757^{c} \\
\pm 0.033\end{array}$ \\
\hline & $\begin{array}{c}\text { containing } 5 \% \text { garlic and } \\
100 \% \text { of protein from } \\
\text { mackerel fish }\end{array}$ & $\begin{array}{r}1.297^{c} \\
\pm 0.185\end{array}$ & $\begin{array}{l}19.400^{d} \\
\pm 0.616\end{array}$ & $\begin{array}{l}0.752^{c} \\
\pm 0.030\end{array}$ \\
\hline
\end{tabular}

All results are expressed as mean \pm SD

Values in each column, which have different litters, are significant different $(P<0.05)$ 


\section{Omnia G. Refaat - Ashraf A. Abd-elmeged and Omnia W.Darwish}

\section{References}

Achike, F.I.; To, N.H.P. and WangHandKwan,C.Y. (2011):

Obesity, metabolic syndrome, adipocytes and vascular function: A holistic viewpoint. Clin. Exp.Pharmacol.Physiol 38:1-10.

Agren, J.J.; Hanninen, O.; Julkunen, A.; Fogelholm, L.; Vidgren, H.; Schwab, U.; Pynnonen, O. and Uusitupa, M. (1996):

Fish diet, fish oil and docosahexaenoic acid rich oil lower fasting and postprandial plasma lipid levels.Eur. J. of Clin.Nutr., 50 (11):765-771.

Allain, C.Z., Poon, L.S. and Chan, C.S (1974):

Enzymatic determination of total serum cholesterol. Clin. Chem., 20: 470-475.

A.O.A.C. (1990):

Official Methods of Analysis of Association of Official Agricultural Chemists, Washington, D.C.

Belfield, A. and Goldberg,D. M. (1971):

Normal Ranges and Diagnostic Value of Serum 5 'Nucleotidase and Alkaline Phosphatase Activities in Infancy. Arch. Dis.Child ;46:842-846.

Block, E. (2010):

Garlic and Other Alliums: The Lore and the Science. Royal Society of Chemistry. ISBN 0-85404-190-7.

Bohmer, H.B.U.M. (1971):

Micro-determination of creatinine. Clin.Chem. Acta, 32: 81-85. 


\section{Egyptian J. of Nutrition Vol. XXXIII No. 2 (2018)}

British Medical Association (BMA) (2005):

Board of Science. Preventing childhood obesity. A report from the BMA Board of Science. BMA publications unit, June 2005.

Burstein, M. (1970):

HDL cholesterol determination after separation high density lipoprotein. Lipid Res. 11: 583.

Chiang, M.T., Chang, S.M. and Liu, H.S. (1995):

Plasma lipoprotein and glucose levels in rats fed a diet high in fish oil. J. of Clin. Nutr. Soc..20(3): 201-214.

Connor, W.E. (2000):

Importance of n-3 fatty acids in health and disease. Am. J. Clin. Nutr.;71: 171S-175.

Daviglus, M.L.; Stamler, J. and Orencia, A.J. (1997):

Fish consumption and the 30-year risk of fatal myocardial infarction. N.Engl. J. Med.;336: 1046-1053.

Dolocek, T.A. and Grandits, G. (1991):

Dietary polyunsaturated fatty acids and mortality in multiple risk factor intervention trial (MRFIT). World Rev. Nutr. Diet; 66: 205-216.

Donadio, J.V. (1991):

Omega-3 polyunsaturated fatty acids: a potential new treatment of immune renal disease. Mayo. Clin. Proc. 66:1018-1028. 


\section{Omnia G. Refaat - Ashraf A. Abd-elmeged and Omnia W.Darwish}

Eidi A.; EidiM. AndEsmaeili E (2006):

Antidiabetic effect of garlic (Allium sativum L.) in Normal and streptozotocin-induced diabetic rats. Phytomed. 13(9):624629.

Elkayam, A.; Mirelman, D.; Peleg, E.; Wilchek, M.; Miron, T.; Rabinkov, A.; Oron-Herman, M. and Rosenthal, T. (2003): The Effects of Allicin on Weight in Fructose-Induced Hyperinsulinemic, Hyperlipidemic, Hypertensive Rats. American Journal of Hypertension; 16:1053-1056.

Fassett, R.G.; Gobe, G.C.; Peake, G.M.; Coombes, G.S. and Metrics, P. (2010):

Omega-3 Polyunsaturated Fatty Acids in the Treatment of Kidney Disease. AJKD, 56 (4): 728-742.

Fossati, P. and Principe, L. (1982):

Enzymatic colorimetric method to determination triglycerides. Clin. Chem. 28, 2077.

Fossati, P.; Prencipe, L. and Berti, G. (1980):

Enzymatic colorimetric method of determination of uric acid in serum. Clin. Chem. 26 (2): 227-273.

Friedman, E.A. (1996):

Bowel as a kidney substitute in renal failure. Am. J. Kidney Dis. 28, 943-950.

Friedwald, W.T.; Levey, R.I. and Fredrickson, D.S. (1972):

Estimation of concentration of low-density lipoprotein separated by three different methods. Clin. Chem., 18: 499502. 


\section{Egyptian J. of Nutrition Vol. XXXIII No. 2 (2018)}

Fujihira, E.; Takahashi, H. and Nakazawa, M. (1970):

Effect of long-term feeding of taurine in hereditary hyperglycemic obese mice. Chem Pharm Bull (Tokyo) 1970; 18: 1636-1642.

Geleijnse, J.M.; Giltay, E.J.; Grobbee, D.E.; Donders, A.R. andKok, F.J. (2002):

Blood pressure response to fish oil supplementation: metaregression analysis of randomized trials. J. Hypertens.; 20: 1493-1499.

Guillaume, M. and Bjorntorp, P. (1996):

Obesity in Children, environmental and genetic aspects. Horm. Metab. Res. 28, 573-581.

Harris, W.S. (1996):

n-3 fatty acids and lipoproteins: comparison of results from human and animal studies. Lipids; 31: 243-252.

Jeyaraj S.; Shivaji G.; Jeyaraj SD. AndVengatesan A. (2006): Effect of combined supplementation of fish oil with garlic pearls on the serum lipid profile in hypercholestrolemic subjects. Indian Heart J. 57(4):327-331.

Josling, P.A. (2005):

The heart of garlic Nature's aid to healing the humanbody, HEC Publishing, Chicago Illinois. pp 20.

Kim, M.J, and Kim, H.K. (2011):

Effect of garlic on high fat induced obesity. ActaBiologicaHungarica 62(3), pp. 244-254. 


\section{Omnia G. Refaat - Ashraf A. Abd-elmeged and Omnia W.Darwish}

Kim, H.R.; Kim, J.H. and Om, A.S. (2013):

Beneficial effects of Allium sativum L. stem extract on lipid metabolism and antioxidant status in obese mice fed a highfat diet. J Sci Food Agric. 30;93 (11):2749-57.

Kuroda, M.; Ohta, M.; Okufuji, T.; Takigami, C.; Eguchi, M.; Hayabuchi, H. and Ikeda, M. (2010):

Frequency of soup intake and amount of dietary fiber intake are inversely associated with plasma leptin concentrations in Japanese adults. Appetite. ;54(3):538-543.

Lau, B.H. (2006):

Suppression of LDL oxidation by garlic compounds is a possible mechanism of cardiovascular health benefit. Nutr; 136 (3): 765S-768S.

Lawson, L.D.; Ransom, D.K. and Hughes, B.G. (1992):

Inhibition of whole blood platelet aggregation by compounds in garlic glove extracts and commercial garlic products. Thromb Res;65:141- 56.

Leaf, A. (1990):

Cardiovascular effects of fish oils: beyond the platelet. Circulation.; 82: 624-628.

Leelarungrayub, N.; Rattanapanone, V.; Chanarat, N. and Gebicki, J.M. (2006):

Quantitative evaluation of the antioxidant properties of garlic and shallot preparations. Nutrition; 22:266- 74. 


\section{Egyptian J. of Nutrition Vol. XXXIII No. 2 (2018)}

Lowe, N.J., Borok, M.E., Ashley, J.M., Alfin, R,B.(1997):

Fish oil consumption reduces hypertriglycerdemia in-patients. Atherosclerosis.127(4): 177-178.

Mahmoodi, M.; Islami, M.R.; AsadiKaram, G.R.; Khaksari, M.; SahebghadamLotfi, A.; Hajizadeh, M.R. and Mirzaee, M.R. (2006):

Study of the effects of raw garlic consumption on the level of lipids and other blood biochemical factors in hyperlipidemic individuals. Pak J Pharm Sci.; 19(4):295-8.

Maldonado, P.D.; Barrera, D.; Campos, O.N.; Hernández-Pando, R.; Elbarra-Rubio, M. and Pedraza-Chaverrí, J. (2003):

Aged garlic extract attenuates gentamicin induced renal damage and oxidative stress in rats. Life Sciences 73(20): 2543-2556.

Min, L.; Ling, S.; Yin, L.; Stephen, C.W.; Randy, J. S.; David, D. and Patrick, T. (2004):

Obesity induced by a high-fat diet down regulates apolipoprotein A-IV gene expression in rat hypothalamus. Am. J. Physiol. EndocrinolMetab., 287: E366-E370.

Miura, T., Ohnish, Y., Takaggi, S., Yamori, N., Seino, Y. (1998):

A comparative study of high fat diets containing fish oil or lard on blood glucose in genetically diabetic mice. J. of Nutrition Science and Vitaminology.43 (2): 225-231. 


\section{Omnia G. Refaat - Ashraf A. Abd-elmeged and Omnia W.Darwish}

Mori, T.A.; Bao, D.Q.; Burke, V.; Puddey, I.B.; Watts, G.F. and Beilin, L.J. (1999):

Dietary fish as a major component of a weight-loss diet: effect on serum lipids, glucose, and insulin metabolism in overweight hypertensive subjects. Am J Clin Nutr.;70:817-25.

Murakami, K.; Sasaki, S.; Takahashi, Y.; Uenishi, K.; Yamasaki, M.; Hayabuchi, H.; Goda, T.; Oka, J.; Baba, K.; Ohki, K.; Watanabe, R. and Sugiyama, Y. (2007):

Nutrient and food intake in relation to serum leptin concentration among young Japanese women. Nutrition. ;23(6):461-468.

Nakatani, T.; Kim, H.J.; Kaburagi, Y.; Yasuda, K. and Ezaki, O. (2003):

A low fish oil inhibits SREBP-1 proteolytic cascade, while a high-fish-oil feeding decreases SREBP-1 mRNA in mice liver: relationship to antiobesity. J Lipid Res; 44: 369-379.

Nestel, P.J. (1990):

Effects of $n-3$ fatty acids on lipid metabolism. Annu. Rev. Nutr. ; 10:149-67.

Ohaeri OC. (2001):

Effects of garlic oil on the levels of various enzymes in the serum and tissue of streptozotocin diabetic rats. Rep. 21:19-24

Patton, C.J. and Crouch, S.R. (1977):

Enzymatic colorimetric method to determination urea in serum. Anal. Chem., 49: 464. 


\section{Egyptian J. of Nutrition Vol. XXXIII No. 2 (2018)}

Peters, J. C. (2003):

Dietary fat and body weight control. Lipids,38:123-127.

Rahman, K. and Lowe, G.M. (2006):

Garlic and cardiovascular disease: a critical review. J Nutr; 136:736S - 40S.

Rayalam, S.; Della-Fera, M.A. and Baile, C.A. (2008):

Phytochemicals and regulation of the adipocyte life cycle. $\mathrm{J}$ NutrBiochem, 19 (11):717-726.

Reeves, P. G.; Nielsen, F. H. and Fahmy, G. C. (1993):

AIN-93 purified diets for laboratory rodents: Final report of the American Institute of Nutrition ad hoc writing committee on the reformulation of the AIN-76A rodent diet. J. Nutr.,123(11):1939-1951.

Rosen, E.D.; C.J. Walkey; P. Puigserver and B.M. Spiegelman (2000):

Transcriptional regulation of adipogenesis. Genes Dev, 14 (11):1293-1307.

Schaefer, E. J., Lichtenstein, A. H., Lamon-Fava, S., Contois, J. H., Li, Z., Goldin, B. R., Rasmussen, H., McNamara, J. R., Ordovas, J. M. (1996):

Effects of National Cholesterol Education Program Step 2 diets relatively high or relatively low in fish-derived fatty acids on plasma lipoproteins in middle-aged and elderly subjects. Am. J. Clin. Nutr. 63:234-241. 


\section{Omnia G. Refaat - Ashraf A. Abd-elmeged and Omnia W.Darwish}

Shiau, Y. and Hwa, S. (1999):

Comparison of park, chicken, mackerel and tilapia containing diets on serum lipids in rats. Nutrition Reports International.40 (4): 783-792.

Soderberg, S.;Ahren, B. and Stegmayr, B. (1999):

Leptin is a risk marker for first-ever hemorrhagic stroke in a population-based cohort. Stroke.; 30: 328-337.

Steel, R.G. and Torri, J.H. (1980):

Principle and Procedures of Statistical Biometrical Approach.2ndedn. Pbi. Mc Grew Hill Book Company; New York; U.S.A.

Tremblay, F.; Lavigne, C.; Jacques, H. and Marette, A. (2007):

Role of dietary proteins and amino acids in the pathogenesis of insulin resistance. Annu Rev Nutr.; 27:293-310.

Trinder, P. (1959):

Determination of blood glucose using 4-aminophenazone. J. Clin. Path., 22: 246.

Viejo, J.M., Terstra, A.H., Bastida, S.C., Sanchez, F.J. (1999):

Small supplementation of $\omega-3$ fatty acids changes serum lowdensity lipoprotein composition. European J. of Nutrition. 38 (1): 20-27. 


\section{Egyptian J. of Nutrition Vol. XXXIII No. 2 (2018)}

World Health organization (1998):

Consultation on obesity. Global prevalence and secular trends in obesity. In: Obesity: preventing and managing the global epidemic. WHO: Geneva, Switzerland, 1998, pp 17-40.

Yoon, J.Y.; Jung, K.O.; Kil, J.H. and Park, K.Y. (2005):

Antiobesity effect of major Korean spices (red pepper powder, garlic, and ginger) in rats fed high fat diet. J Food Sci Nutr;10:58e63.

Yu Wei Feng.; Li Zhen Ma.; Yu Can Du.; San Hong Fan. AndRui Tong Dai. (2012):

chemical composition Analysis of Three commercially Important Fish Species (Sardine, Anchovy and Mackerel). Advanced Materials Research, Vols. 554-556, pp. 900904,2012 .

Zhang, C., Beynen, A., Xizhong, L. (1993):

Influence of dietary fish proteins on plasma and liver cholesterol concentration in rats. Br. J. Nutri. 69 (3): 767-777. 


\title{
Omnia G. Refaat - Ashraf A. Abd-elmeged and Omnia W.Darwish
}

تأثير الثوم و سمك الماكريل علي الفئران المصابة بالسمنة

\author{
أمنية جلال رفعت ـ أشرف عبد العزيز عبد المجيا ـ أمنية وليد درويش \\ قسم التغذيه و علوم الأطعمه ـ كليه الاقتصاد المنزلى - جامعه حلوان \\ الملخص العربي
}

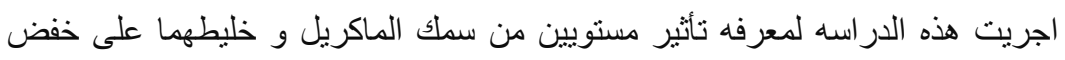

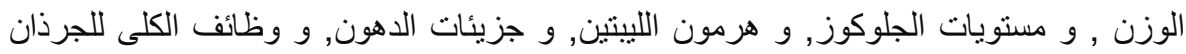

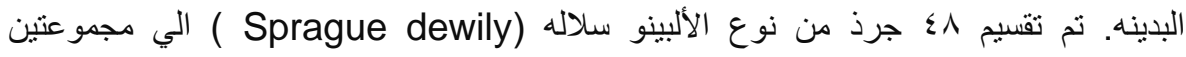

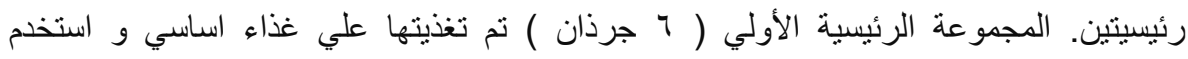

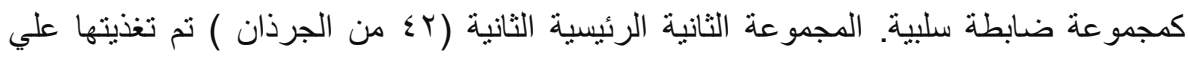

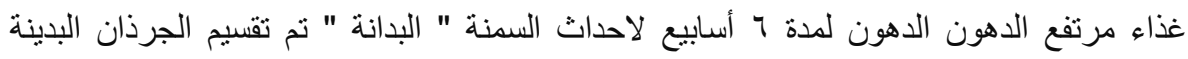

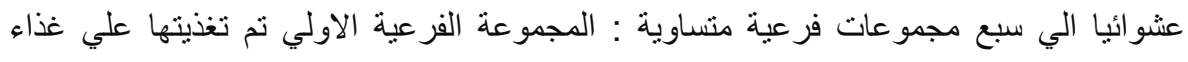

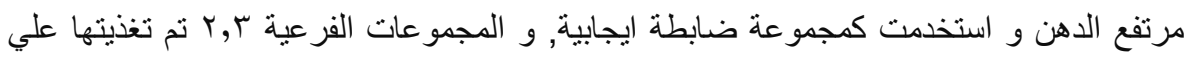

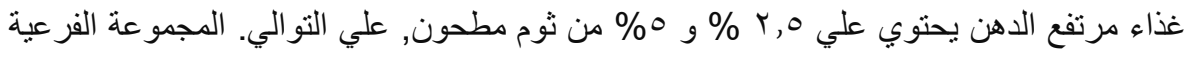

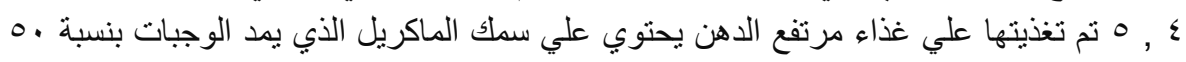

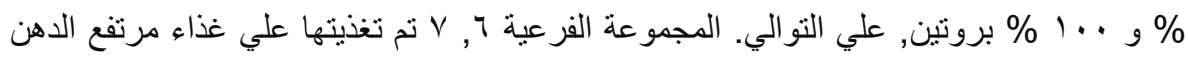

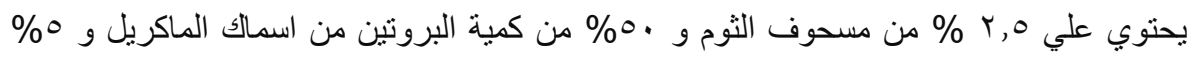

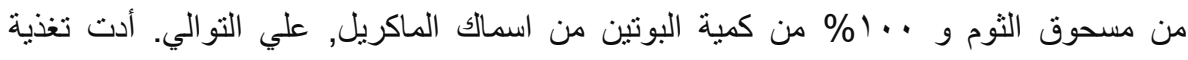

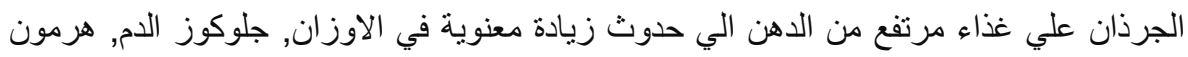

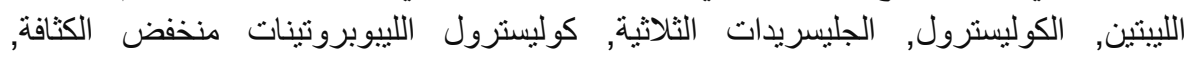

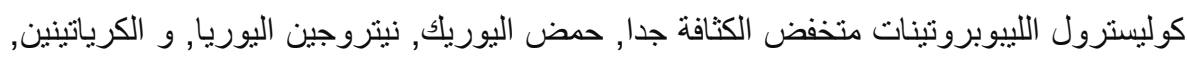

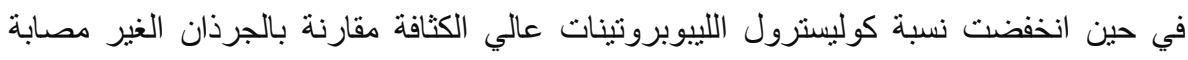

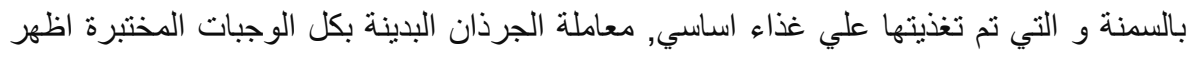

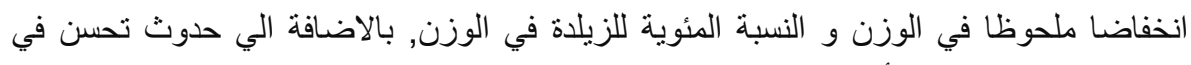

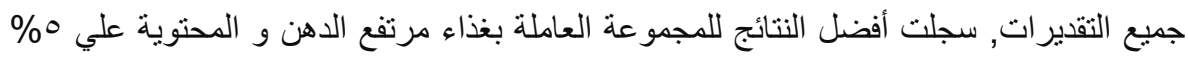

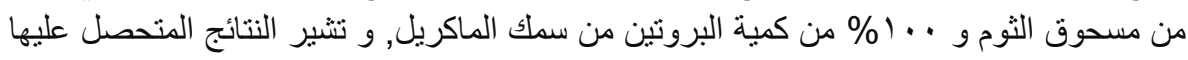

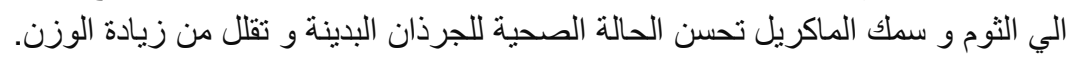

